\title{
Productive and vegetative performance of peach trees grafted on six rootstocks in a replanting area
}

\author{
Gustavo Klamer de Almeida(1), Gilmar Arduino Bettio Marodin(2), \\ Henrique Thomas Queiroz ${ }^{(3)}$ and Mateus Pereira Gonzatto ${ }^{(4)}$
}

\begin{abstract}
(1)Universidade Federal do Rio Grande do Sul (UFRGS), Faculdade de Agronomia, Departamento de Horticultura e Silvicultura, Programa de Pós-Graduação em Fitotecnia, Avenida Bento Gonçalves, no 7.712, CEP 91540-000 Porto Alegre, RS, Brazil. E-mail: gklalmeida@hotmail.com (2)UFRGS, Faculdade de Agronomia, Departamento de Horticultura e Silvicultura, Avenida Bento Gonçalves, no 7.712, CEP 91540-000 Porto Alegre, RS, Brazil. E-mail: marodin@ufrgs.br ${ }^{(3)}$ Empresa de Assistência Técnica e Extensão Rural do Rio Grande do Sul, Rua Botafogo, no 1.051, CEP 90150-053 Porto Alegre, RS, Brazil. E-mail: henrique.agro@yahoo.com.br (4)UFRGS, Faculdade de Agronomia, Estação Experimental Agronômica, BR-290, Km 146, CEP 92990-000 Eldorado do Sul, RS, Brazil. E-mail: mpgonzatto@gmail.com
\end{abstract}

\begin{abstract}
The objective of this work was to evaluate the productive and vegetative performance of the Maciel and Chimarrita peach tree cultivars grafted on six rootstocks, in a replanting area. The experiment was carried out in an area that had been previously cultivated with peach trees for more than 15 years in the municipality of Eldorado do Sul, in the state of Rio Grande do Sul, Brazil. The Maciel and Chimarrita peach tree cultivars were grafted on 'Aldrighi', 'Capdeboscq', 'Okinawa', 'Flordaguard', 'Nemaguard', and 'Umezeiro'. The 'Umezeiro' rootstock caused high plant mortality in both scions, as well as low productivity and higher alternate bearing; it also affected the qualitative and ripening attributes of the fruits of 'Chimarrita'. The 'Aldrighi', 'Capdeboscq', 'Okinawa', 'Flordaguard', and 'Nemaguard' rootstocks induced a similar yield in both scions. The trunk crosssectional area (TCSA) did not differ between rootstocks in 'Maciel', but in 'Chimarrita', TCSA was higher on 'Flordaguard' than on 'Umezeiro' in some seasons. Regarding the average of rootstocks, 'Maciel' showed higher TCSA, pruning mass, and average yield than 'Chimarrita', as well as changes in qualitative and ripening attributes. The Maciel cultivar shows the best productive performance in replanting areas, and the 'Capdeboscq' and 'Aldrighi' rootstocks induce satisfactory agronomic performance.
\end{abstract}

Index terms: Prunus persica, plant mortality, replant disease, yield.

\section{Desempenho produtivo e vegetativo de pessegueiros enxertados sobre seis porta-enxertos em uma área de replantio}

\begin{abstract}
Resumo - O objetivo deste trabalho foi avaliar o desempenho produtivo e vegetativo das cultivares de pessegueiro Maciel e Chimarrita enxertadas em seis porta-enxertos, em área de replantio. O experimento foi implantado em uma área anteriormente cultivada com pessegueiro por mais de 15 anos, no Município de Eldorado do Sul, Rio Grande do Sul. As cultivares de pessegueiro Maciel e Chimarrita foram enxertadas sobre 'Aldrighi', 'Capdeboscq', 'Okinawa', 'Flordaguard', 'Nemaguard' e 'Umezeiro'. O porta-enxerto 'Umezeiro' induziu alta mortalidade de plantas nas duas cultivares-copa, além de baixa produtividade e maior alternância de produção; também afetou os aspectos qualitativos e de maturação dos frutos de 'Chimarrita'. Os porta-enxertos 'Aldrighi', 'Capdeboscq', 'Okinawa', 'Flordaguard' e 'Nemaguard' induziram produtividade semelhante nas duas cultivares-copa. A área da seção transversal do tronco (TCSA) não diferiu entre os porta-enxertos em 'Maciel', porém, em 'Chimarrita', a TCSA foi maior sobre 'Flordaguard' do que sobre 'Umezeiro', em algumas safras. Na média dos porta-enxertos, 'Maciel' apresentou maior TCSA, massa de poda e produtividade média que 'Chimarrita', além de diferenças em atributos qualitativos e de maturação dos frutos. A cultivar Maciel apresenta melhor desempenho produtivo em áreas de replantio, e os porta-enxertos 'Capdeboscq' e 'Aldrighi' induzem desempenho agronômico satisfatório.
\end{abstract}

Termos para indexação: Prunus persica, mortalidade de plantas, doenças de replantio, produtividade.

\section{Introduction}

Replant diseases are common in many regions of the world, occurring when stone fruit are planted on soils that have been previously cultivated with similar species
(Bent et al., 2009). The causes of replant diseases are still unknown, although many factors appear to be involved. The action of fungi, nematodes, and bacteria can be direct (parasitism) or indirect, possibly due to the hydrolysis of prunasin, through the decomposition

Pesq. agropec. bras., Brasília, v.51, n.4, p.364-371, abr. 2016

DOI: 10.1590/S0100-204X2016000400009 
of root tissue from previous crops, which generates hydrocyanic acid, a phytotoxic compound associated with replant diseases (Gur \& Cohen, 1989; Benizri et al., 2005).

In plants, the most characteristic effects of replant diseases are the reduction of vigor and yield, besides the orchard's low longevity (Rutto \& Mizutani, 2006; Bent et al., 2009). Soil fumigation with chemical compounds has been used as a control technique, resulting in an increase in plant growth and yield, but it still presents low efficiency levels, high implementation costs, and a risk to human health and to the environment (Leinfelder \& Merwin, 2006).

Other attempts to increase the vegetative growth of peach trees were carried out by inoculating mycorrhizal fungi in the roots. Under controlled conditions, in a substrate sterilized with formaldehyde, some mycorrhizal fungi species induced an increase in vegetative growth and improved the nutritional status of the 'Okinawa' peach tree, until 330 days after sowing (Nunes et al., 2011). However, when the seeds were planted in soil taken from the replanting area or even from an area that had never been planted with peach trees, inoculation with mycorrhizal fungi showed no effect on plant growth or nutrition (Rutto \& Mizutani, 2006).

The use of resistant rootstocks has been recommended as a viable and efficient alternative to overcome the problems in peach tree replanting areas. Studies have shown a good performance of the 'Evrica', 'PAC 9801-02', 'ROOTPAC 40', and 'Tetra' rootstocks (Pinochet, 2010; Jiménez et al., 2011). However, these rootstocks are not available in Brazil, where there are no known studies on the performance of different rootstocks for peach tree replanting areas.

The objective of this work was to evaluate the productive and vegetative performance of the Maciel and Chimarrita peach tree cultivars grafted on six rootstocks, in a replanting area.

\section{Materials and Methods}

The experiment was conducted in the municipality of Eldorado do Sul, in the state of Rio Grande do Sul, Brazil, in the Agricultural Experimental Station of Universidade Federal do Rio Grande do Sul $\left(30^{\circ} 06^{\prime} 50^{\prime \prime} \mathrm{S}, 51^{\circ} 39^{\prime} 48^{\prime \prime} \mathrm{W}\right)$, in a Argilossolo Vermelho distrófico típico (Rhodic Ultisol). The climate of the region is humid temperate, with a hot summer, $\mathrm{Cfa}$ according toKöppen's classification. The average annual temperature is $18.8^{\circ} \mathrm{C}$, and the average annual rainfall is $1,445 \mathrm{~mm}$ (Bergamaschi et al., 2013). The area had been previously cultivated with 'Maciel'/'Capdeboscq' peach trees for more than 15 years, with a three-year period between the elimination of the orchard and the installation of the experiment. Planting was carried out in 2006 , with a $1.5 \times 5.5-\mathrm{m}$ spacing $(1,212$ plants per hectare), in a "Y" system. The assays were performed in eight growing seasons.

The experiment was established in a randomized complete block design, with three replicates composed of five plants each, with the central three as the useful ones. The treatments were arranged in a $2 \times 6$ factorial arrangement (scion $\mathrm{x}$ rootstock). The 'Maciel' (dual purpose) and 'Chimarrita' (in nature) [both Prunus persica (L.) Batsch] scions were grafted on the 'Aldrighi' ( $P$. persica), 'Capdeboscq' ( $P$. persica), 'Flordaguard' ( $P$. persica x P. davidiana Franch.), 'Nemaguard' ( $P$. persica x $P$. davidiana), 'Okinawa' (P. persica), and 'Umezeiro' ( $P$. mume Siebold \& Zucc.) rootstocks. All rootstocks were propagated by seed, and the scions were grafted by the inverted "T" method, during the summer of 2005.

To estimate the vegetative growth of the scion/ rootstock combinations, the following were determined: trunk cross-sectional area (TCSA), using the equation TCSA $\left(\mathrm{cm}^{2}\right)=\left(\pi \mathrm{D}^{2}\right) / 4$, in which $\mathrm{D}$ is the diameter measured $10 \mathrm{~cm}$ above the grafting point (López-Ortega et al., 2016); and pruning mass of branches that had been removed in green pruning, in December, and in dry pruning, before the beginning of bud burst. Plant mortality was quantified in each combination annually. The productive performance was evaluated using the yield of seven seasons, from the second to the eighth year after planting. For yield estimate, the production per plant $(\mathrm{kg})$ was multiplied by the actual number of plants per hectare, fixing the plant stand for the combinations that showed mortality every year. The average fruit mass (FM) was obtained by relating each plant production to the number of fruits, in all the seasons.

To determine qualitative and ripening attributes, ten fruit samples per experimental unit were collected in three seasons (2011/2012, 2012/2013, and 2013/2014). The following traits were measured: pulp firmness, expressed in Newton; the length/diameter ratio, by measuring the length and diameter of the fruit; soluble solid (SS) content, expressed in ${ }^{\circ}$ Brix; and titratable 
acidity (TA), expressed in gram per $100 \mathrm{~mL}^{-1}$ malic acid. Data on fruit color were obtained with the Konica Minolta colorimeter, model CR-400, (Konica Minolta Sensing Americas, Inc., Ramsey, NJ, USA), which was used to determine the values of $\mathrm{L}^{*}, \mathrm{a}^{*}, \mathrm{~b}^{*}$, hue angle $\left(\mathrm{h}^{\circ}\right)$, and chromaticity $\left(\mathrm{C}^{*}\right)$ (McGuire, 1992). A previous analysis of the qualitative and ripening data indicated significant differences only in the average of seasons, for which the analysis of variance (Anova) was carried out.

The data collected in the same experimental unit over time was analyzed as repeated measures using Proc Mixed of SAS, version 9.4 (SAS Institute Inc., Cary, $\mathrm{NC}, \mathrm{USA}$ ). The covariance structure that presented the best adjustment to the data was selected, according to the Akaike (AIC) and Bayesian (BIC) criterion (Freitas et al., 2005). For the other variables, a factorial analysis was carried out, with blocks as a random effect, also using Proc Mixed. Interactions between factors were considered significant when $p \leq 0.25$ (Perecin \& Cargnelutti Filho, 2008). When necessary, Tukey's test was performed, at 5\% probability, to compare means.

\section{Results and Discussion}

Differences were observed in plant vegetative growth, productivity, survival rate, and qualitative and ripening attributes among scions grafted on different rootstocks. A scion-rootstock-year interaction regarding the TCSA variable was also found (Table 1). Unfoldment in the analysis of each scion, over time, indicated differences among rootstocks (Figure 1). In 'Chimarrita', 'Umezeiro' induced lower TCSA than the other rootstocks in 2010 and 2011, in the fourth and fifth years after planting; the other rootstocks

Table 1. Significance values for trunk cross-sectional area (TCSA), pruning mass (PM), and yield of the 'Maciel' and 'Chimarrita' peach (Prunus persica) trees grafted on different rootstocks, in a replanting area.

\begin{tabular}{|c|c|c|c|c|c|}
\hline \multirow[t]{2}{*}{ Variation source } & \multicolumn{2}{|c|}{ TCSA } & \multicolumn{2}{|r|}{ PM } & \multirow{2}{*}{$\frac{\text { Yield }}{\text { F test } P \text {-value }}$} \\
\hline & F test & P-value & $\mathrm{F}$ test & P-value & \\
\hline Scion & 2.72 & 0.106 & 69.17 & $<0.0001$ & $44.38<0.0001$ \\
\hline Rootstock & 13.4 & $<0.0001$ & 13.53 & $<0.0001$ & $9.63<0.0001$ \\
\hline Scion $\times$ Rootstock & 6.81 & $<0.0001$ & 1.40 & 0.264 & 0.339 \\
\hline Year & 730.59 & $<0.0001$ & 290.45 & $<0.0001$ & $34.23<0.0001$ \\
\hline Scion $\times$ Year & 1.50 & 0.206 & 3.60 & $<0.0001$ & $22.45<0.0001$ \\
\hline Rootstock $\times$ Year & 2.49 & 0.004 & 21.31 & $<0.0001$ & 0.455 \\
\hline Scion $\times$ Rootstock $\times$ Year & 1.77 & 0.049 & 0.63 & 0.877 & 0.359 \\
\hline
\end{tabular}

Pesq. agropec. bras., Brasília, v.51, n.4, p.364-371, abr. 2016 DOI: 10.1590/S0100-204X2016000400009 induced similar TCSA. Furthermore, in 2012 and 2014, no difference was observed among rootstocks. In 'Maciel', the rootstocks did not affect TCSA in any of the evaluated seasons.

Some works performed in replanting areas also showed differences among rootstocks regarding TCSA. Jiménez et al. (2011) evaluated the 'Calrico' peach tree on 15 rootstocks in an area previously cultivated with peach trees for 14 years and found that, in the seventh year, the 'Garnem' and 'PADAC 9907-23' rootstocks exhibited a higher TCSA. In the 'Jesca' peach tree, the 'GF-677' x 'Nemaguard', 'Garnem', 'Monegro', and 'Felinem' interspecific hybrids induced a higher TCSA in an area previously cultivated with peach trees for more than 20 years (Alonso \& Espada, 2011). Remorini et al. (2015) assessed the performance of nine rootstocks in an area previously cultivated for 15 years with peach trees, and observed a higher TCSA in 'Flavorcrest' when grafted on the 'Barrier 1' and 'GF 677' hybrids.

In Brazilian conditions, there are no known studies concerning the performance of rootstocks in replanting areas. When evaluating the same scions and rootstocks as those of the present study, other authors obtained different trunk diameters. Comiotto et al. (2013) found that 'Umezeiro' induced lower trunk diameter than 'Flordaguard' in 'Chimarrita', as well as lower trunk diameter than 'Okinawa' in 'Maciel'. Galarça et al. (2013), using the same combinations but in different locations, stated that 'Umezeiro' showed lower trunk diameter than 'Flordaguard', 'Aldrighi', 'Capdeboscq', 'Okinawa', and 'Nemaguard'.

Regarding pruning mass, scion-year and rootstock-year interactions were observed, indicating differences among rootstocks in the average of scions and among scions in the average of rootstocks (Table 1). Among rootstocks, 'Umezeiro' induced lower pruning mass than the others in 2009 and 2010 (Figure 1), whereas, between scions, 'Maciel' showed a higher pruning mass than 'Chimarrita' in 2009, 2011, and 2012. Remorini et al. (2015) also reported differences among rootstocks in replanting areas, in which rootstocks that induced higher TCSA showed higher pruning mass. In 'Maciel' and 'Chimarrita', in most conditions assessed by Galarça et al. (2013), 'Umezeiro' induced a lower pruning mass. However, Comiotto et al. (2013), using the same combinations of scion/rootstock, did not observe any differences among rootstocks. 
At the end of present study, the rootstocks showed similar vegetative growth. This fact might be related with the number of plants per plot, reduced in some of the combinations due to plant mortality during the experiment, which decreased the competition inside the plot. The lowest survival rate was observed in scions grafted on 'Umezeiro', which exhibited incompatibility symptoms, with breakage of the trunk in the graft zone (Table 2). Graft incompatibility symptoms were also detected by Comiotto et al. (2013) for the same scions grafted on 'Umezeiro'. However, plant death was not observed in any of the scions on the 'Aldrighi' and 'Capdeboscq' peach trees. Other studies also showed plant mortality in replanting conditions. Remorini et al. (2015) registered maximum mortality of $20 \%$ and Jiménez et al. (2011) of 75\% for tested rootstocks.

Yield showed a scion-year interaction, with differences among scions in some seasons, in the average of rootstocks (Table 1), in which 'Maciel' had higher productivity than 'Chimarrita' in two out of seven
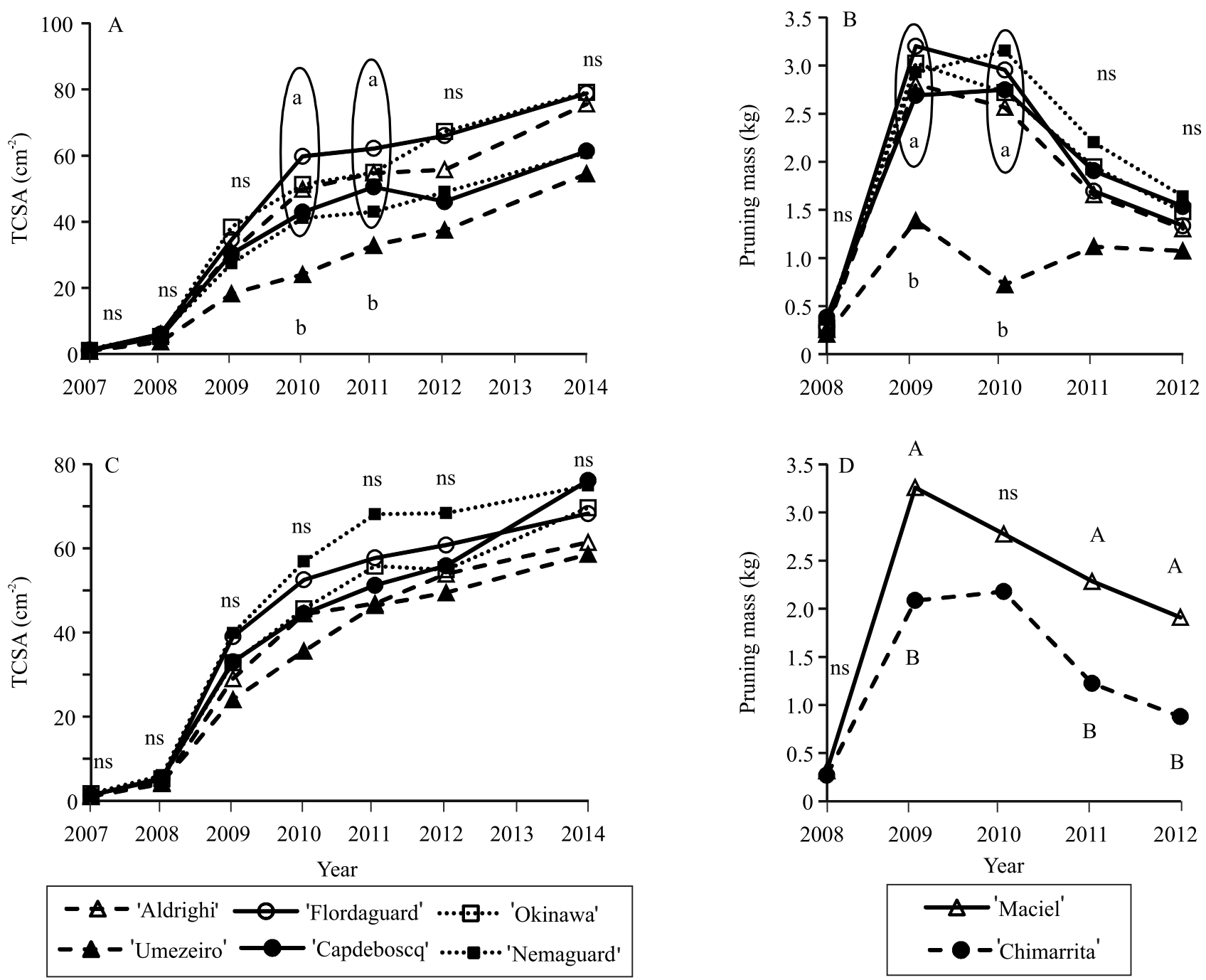

Figure 1. Trunk cross-sectional area (TCSA) of the 'Chimarrita' (A) and 'Maciel' (B) scions grafted on six rootstocks, until the eighth experimental year, as well as pruning mass of 'Maciel' and 'Chimarrita' in the average of rootstocks (C) and in the average of scions on six rootstocks (D), in five seasons, in a replanting area. Uppercase letters compare scions according to the $\mathrm{F}$ test, at $5 \%$ probability, whereas lowercase letters compare rootstocks according to Tukey's test, at 5\% probability.

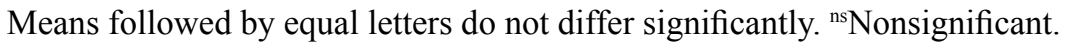


seasons, i.e., 2009 and 2012 (Table 2). Rootstock main effect was also observed, indicating that the difference among rootstocks lies in the average of scions and in the average of seasons. 'Umezeiro' induced a lower average yield, of only $4.20 \mathrm{Mg} \mathrm{ha}^{-1}$, which is half of the yield for 'Capdeboscq', of $8.9 \mathrm{Mg} \mathrm{ha}^{-1}$.

The yield obtained in the present study can be considered low in comparison to those of other studies in replanting areas. For 'Jesca' peach trees, Alonso et al. (2011) found that yield varied from 10 to $11 \mathrm{Mg} \mathrm{ha}^{-1}$ among rootstocks, in the average of seven seasons; for 'Flavorcrest', Remorini et al. (2015) reported an average yield between 7.5 and $13.9 \mathrm{Mg} \mathrm{ha}^{-1}$ on different rootstocks; and, for 'Calrico' on different rootstocks, Jiménez et al. (2011) observed yield from 6 to $14 \mathrm{Mg} \mathrm{ha}^{-1}$. The differences between these results and those of the present study may be related to the fact that other scion and rootstocks were evaluated, which were possibly better adapted to replanting conditions. Moreover, the cited works used irrigation systems, which prevent hydric stress conditions.
Yield was also below those obtained in other studies in Brazilian conditions with the same combinations of scion/rootstock. Picolotto et al. (2009) reported an average yield of $11.1 \mathrm{Mg} \mathrm{ha}^{-1}$ for 'Chimarrita' on 'Capdeboscq' and of $11.86 \mathrm{Mg} \mathrm{ha}^{-1}$ on 'Okinawa'. According to Galarça et al. (2013), yield varied from 1.1 to $17.7 \mathrm{Mg} \mathrm{ha}^{-1}$ for 'Chimarrita' and from 4.3 to 25.2 $\mathrm{Mg} \mathrm{ha}^{-1}$ for 'Maciel', on different rootstocks and in different locations. However, these studies were not conducted in replanting areas, which may affect plant growth and result in lower yield, as pointed out by Rutto \& Mizutani (2006). During the experiment, a high incidence of Monilinia fructicola for both scions was observed in any season, which caused serious damage to the fruit and also the death of new branches.

The cumulative yield showed rootstock and scion main effect (Table 2). 'Maciel' produced $61.9 \mathrm{Mg} \mathrm{ha}^{-1}$, in the sum of seven seasons, and 'Chimarrita' $40.8 \mathrm{Mg} \mathrm{ha}^{-1}$. Among the rootstocks, 'Umezeiro' induced the worst performance, of only $29.4 \mathrm{Mg} \mathrm{ha}^{-1}$, when compared to the other five, whose cumulative

Table 2. Yield, cumulative yield (CY), and plant survival rate (S) of the 'Maciel' and 'Chimarrita' peach (Prunus persica) trees grafted on different rootstocks, until the eighth experimental year, in a replanting area ${ }^{(1)}$.

\begin{tabular}{|c|c|c|c|c|c|c|c|c|c|}
\hline \multirow[t]{2}{*}{ Rootstock } & \multicolumn{7}{|c|}{ Yield $\left(\mathrm{Mg} \mathrm{ha}^{-1}\right)$} & \multirow{2}{*}{$\begin{array}{c}\mathrm{CY} \\
\left(\mathrm{Mg} \mathrm{ha}^{-1}\right)\end{array}$} & \multirow{2}{*}{$\begin{array}{c}\mathrm{S} \\
(\%)\end{array}$} \\
\hline & 2008 & 2009 & 2010 & 2011 & 2012 & 2013 & 2014 & & \\
\hline & \multicolumn{9}{|c|}{ 'Maciel' } \\
\hline 'Aldrighi' & $7.7^{\mathrm{ns}}$ & $11.1^{\mathrm{ns}}$ & $2.7^{\mathrm{ns}}$ & $10.8^{\mathrm{ns}}$ & $12.3^{\mathrm{ns}}$ & $13.4^{\mathrm{ns}}$ & $11.1^{\mathrm{ns}}$ & $69.2^{\mathrm{ns}}$ & 100 \\
\hline 'Capdeboscq' & 6.1 & 13.1 & 6.1 & 12.0 & 17.6 & 10.0 & 13.4 & 78.3 & 100 \\
\hline 'Flordaguard' & 8.5 & 13.7 & 5.6 & 11.8 & 11.2 & 9.3 & 9.2 & 69.3 & 100 \\
\hline 'Nemaguard' & 6.2 & 11.0 & 3.2 & 13.9 & 13.2 & 8.5 & 9.7 & 65.5 & 100 \\
\hline 'Okinawa' & 5.7 & 12.0 & 1.1 & 8.5 & 11.9 & 7.9 & 3.1 & 50.2 & 100 \\
\hline 'Umezeiro' & 3.2 & 6.3 & 1.3 & 5.6 & 8.0 & 6.5 & 7.8 & 38.6 & 60.0 \\
\hline \multirow[t]{2}{*}{ Average } & $6.2^{\mathrm{ns}}$ & $11.2 \mathrm{~A}$ & $3.3^{\mathrm{ns}}$ & $10.4^{\mathrm{ns}}$ & $12.3 \mathrm{~A}$ & $9.3^{\mathrm{ns}}$ & $9.0^{\mathrm{ns}}$ & $61.9 \mathrm{~A}$ & 93.3 \\
\hline & \multicolumn{9}{|c|}{ 'Chimarrita' } \\
\hline 'Aldrighi' & $5.4^{\mathrm{ns}}$ & $3.0^{\mathrm{ns}}$ & $3.6^{\mathrm{ns}}$ & $7.2^{\mathrm{ns}}$ & $8.5^{\mathrm{ns}}$ & $12.2^{\mathrm{ns}}$ & $4.1^{\mathrm{ns}}$ & $44.0^{\mathrm{ns}}$ & 100 \\
\hline 'Capdeboscq' & 4.4 & 2.0 & 2.5 & 10.4 & 10.9 & 13.0 & 4.0 & 47.1 & 100 \\
\hline 'Flordaguard' & 5.2 & 1.2 & 2.8 & 12.6 & 7.3 & 13.6 & 4.8 & 47.5 & 87.0 \\
\hline 'Nemaguard' & 4.5 & 3.2 & 2.5 & 7.0 & 4.6 & 18.0 & 2.2 & 42.0 & 73.0 \\
\hline 'Okinawa' & 4.5 & 2.1 & 3.5 & 11.1 & 6.1 & 13.2 & 3.7 & 44.2 & 80.0 \\
\hline 'Umezeiro' & 1.3 & 0.0 & 0.0 & 1.8 & 2.4 & 10.4 & 4.2 & 20.2 & 60.0 \\
\hline \multirow[t]{2}{*}{ Average } & 4.2 & $1.9 \mathrm{~B}$ & 2.5 & 8.4 & $6.6 \mathrm{~B}$ & 13.4 & 3.8 & $40.8 \mathrm{~B}$ & 83.3 \\
\hline & \multicolumn{9}{|c|}{ Average of the scions } \\
\hline 'Aldrighi' & $6.6^{\mathrm{ns}}$ & $7.1^{\mathrm{ns}}$ & $3.2^{\mathrm{ns}}$ & $9.0^{\mathrm{ns}}$ & $10.4^{\mathrm{ns}}$ & $12.8^{\text {ns }}$ & $7.6^{\mathrm{ns}}$ & $56.6 \mathrm{a}$ & 100 \\
\hline 'Capdeboscq' & 5.2 & 7.5 & 4.3 & 11.2 & 14.2 & 11.5 & 8.7 & $62.7 \mathrm{a}$ & 100 \\
\hline 'Flordaguard' & 6.9 & 7.5 & 4.2 & 12.2 & 9.2 & 11.5 & 7.0 & $58.4 \mathrm{a}$ & 93.3 \\
\hline 'Nemaguard' & 5.4 & 7.1 & 2.8 & 10.4 & 8.9 & 13.2 & 6.0 & $53.8 \mathrm{a}$ & 86.7 \\
\hline 'Okinawa' & 5.1 & 7.1 & 2.3 & 9.8 & 9.0 & 10.5 & 3.4 & $47.2 \mathrm{a}$ & 90.0 \\
\hline 'Umezeiro' & 2.2 & 3.1 & 0.6 & 3.7 & 5.2 & 8.5 & 6.0 & $29.4 \mathrm{~b}$ & 60.0 \\
\hline
\end{tabular}

${ }^{(1)}$ Uppercase letters compare scions according to the $\mathrm{F}$ test, at $5 \%$ probability, and lowercase letters compare rootstocks according to Tukey's test, at $5 \%$ probability. Means followed by equal letters do not differ significantly. ${ }^{n s}$ Nonsignificant. 
yield ranged from 47.2 to $62.7 \mathrm{Mg} \mathrm{ha}^{-1}$, in the average of scions. These values can be considered low in comparison with those obtained by Alonso \& Espada (2011) and Remorini et al. (2015), who studied other scions in replanting conditions. This fact could be attributed to the low plant growth observed in the present study. In Brazilian conditions, the works with the same scion/rootstock combinations were carried out in a few seasons, which complicates comparisons with the results of the present study.

Both scions and rootstocks affected qualitative attributes (Table 3). For average FM, a scion main effect was observed. 'Maciel' showed a higher FM than 'Chimarrita' in the average of rootstocks. However, FM was not affected by rootstocks. This result corroborates those of Picolotto et al. (2009), who did not find differences among rootstocks for the 'Chimarrita' peach tree. Aspects related with fruit color also vary among rootstocks, mainly in 'Chimarrita', in which 'Umezeiro' induced lower hue and luminosity and higher $\mathrm{C}^{*}$. It should be noted that a higher hue value indicates a

Table 3. Fruit mass (FM), length/diameter ratio (L/D), hue angle $\left(\mathrm{h}^{\circ}\right)$, lightness $\left(\mathrm{L}^{*}\right)$, and chromaticity $\left(\mathrm{C}^{*}\right)$ of the 'Maciel' and 'Chimarrita' peach (Prunus persica) trees grafted on different rootstocks, in a replanting area ${ }^{(1)}$.

\begin{tabular}{|c|c|c|c|c|c|}
\hline Rootstock & FM (g) & $\mathrm{L} / \mathrm{D}$ & $\mathrm{h}^{\circ}$ & $\mathrm{L}^{*}$ & $\mathrm{C}^{*}$ \\
\hline & \multicolumn{5}{|c|}{ 'Maciel' } \\
\hline 'Aldrighi' & $146.2^{\mathrm{ns}}$ & $0.97^{\mathrm{ns}}$ & $86.6^{\mathrm{ns}}$ & $67.1^{\mathrm{ns}}$ & $10.7^{\mathrm{ns}}$ \\
\hline 'Capdeboscq' & 140.5 & 0.96 & 87.8 & 66.9 & 10.4 \\
\hline 'Flordaguard' & 136.7 & 0.96 & 95.0 & 67.5 & 10.7 \\
\hline 'Nemaguard' & 140.0 & 0.97 & 88.5 & 67.4 & 10.4 \\
\hline 'Okinawa' & 137.7 & 0.96 & 89.2 & 66.6 & 10.2 \\
\hline 'Umezeiro' & 143.4 & 0.97 & 89.9 & 66.9 & 10.1 \\
\hline \multirow[t]{2}{*}{ Average } & $140.7 \mathrm{~A}$ & $0.96 \mathrm{~B}$ & $89.5 \mathrm{~A}$ & $67.1 \mathrm{~A}$ & $10.4 \mathrm{~B}$ \\
\hline & \multicolumn{5}{|c|}{ 'Chimarrita' } \\
\hline 'Aldrighi' & $118.9^{\text {ns }}$ & $0.96^{\mathrm{ns}}$ & $68.1 \mathrm{ab}$ & $57.5 \mathrm{ab}$ & $13.6 \mathrm{~b}$ \\
\hline 'Capdeboscq' & 115.2 & 0.97 & $67.8 \mathrm{ab}$ & $57.6 \mathrm{ab}$ & $13.5 \mathrm{~b}$ \\
\hline 'Flordaguard' & 116.1 & 0.98 & $65.8 \mathrm{ab}$ & $57.5 \mathrm{ab}$ & $14.9 \mathrm{~b}$ \\
\hline 'Nemaguard' & 112.9 & 0.98 & $72.1 \mathrm{a}$ & $58.7 \mathrm{ab}$ & $11.8 \mathrm{~b}$ \\
\hline 'Okinawa' & 116.7 & 0.97 & $75.9 \mathrm{a}$ & $59.7 \mathrm{a}$ & $10.8 \mathrm{~b}$ \\
\hline 'Umezeiro' & 114.1 & 0.97 & $56.4 \mathrm{~b}$ & $54.9 \mathrm{~b}$ & $19.9 \mathrm{a}$ \\
\hline Average & $115.6 \mathrm{~B}$ & $0.97 \mathrm{~A}$ & $67.7 \mathrm{~B}$ & $57.7 \mathrm{~B}$ & $14.1 \mathrm{~A}$ \\
\hline Effect & \multicolumn{5}{|c|}{$\mathrm{p}$-value $(\mathrm{F} \text { test })^{(2)}$} \\
\hline Scion & $<0.001$ & 0.045 & $<0.001$ & $<0.001$ & $<0.001$ \\
\hline Rootstock & 0.284 & 0.865 & 0.034 & 0.218 & $<0.001$ \\
\hline Scion $\mathrm{x}$ Rootstock & 0.559 & 0.631 & 0.007 & 0.175 & $<0.001$ \\
\hline
\end{tabular}

${ }^{(1)}$ Uppercase letters compare scions according to the $\mathrm{F}$ test, at $5 \%$ probability, whereas lowercase letters compare rootstocks according to Tukey's test, at $5 \%$ probability. ${ }^{(2)}$ Significant interaction when $\mathrm{p}<0.25$. Means followed

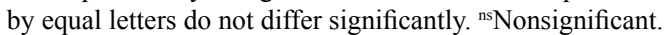

more reddish color of fruits, which makes them more attractive to the consumer. Changes in $\mathrm{L}^{*}$ and $h^{\circ}$ were also reported by Picolotto et al. (2009) for the fruit of 'Chimarrita' peach trees grafted on different rootstocks. However, these variables were not evaluated in other studies.

Alterations were also observed in fruit ripening time due to rootstock effect (Table 4). These changes were shown by the higher contents of SS and of the SS/TA ratio in the fruits of 'Chimarrita' on 'Umezeiro', and by the higher pulp firmness, in the average of scions, induced by 'Umezeiro'. Comiotto et al. (2013), while evaluating the same scions and rootstocks of the present study, did not observe any differences between rootstocks for SS, but found that 'Umezeiro' induced a lower SS/TA ratio than the other rootstocks. However, Orazem et al. (2011) did report alterations in the maturation point due to rootstock effect. These authors found differences in the contents of soluble sugars and of acids among rootstocks. The rootstock effect on the

Table 4. Soluble solids (SS), titratable acidity (TA), soluble solids/titratable acidity ratio (SS/TA), and pulp firmness (F) of the 'Maciel' and 'Chimarrita' peach (Prunus persica) trees grafted on different rootstocks, in a replanting area ${ }^{(1)}$.

\begin{tabular}{lcccc}
\hline Rootstock & $\begin{array}{c}\text { SS } \\
\left({ }^{\circ} \text { Brix }\right)\end{array}$ & $\begin{array}{c}\text { TA (g of malic } \\
\left.\text { acid 100 } \mathrm{mL}^{-1}\right)\end{array}$ & SS/TA & $\begin{array}{c}\mathrm{F}^{(2)} \\
\text { (Newton) }\end{array}$ \\
\hline 'Aldrighi' & $13.0^{\mathrm{ns}}$ & $1.1^{\mathrm{ns}}$ & $12.6^{\mathrm{ns}}$ & $37.5 \mathrm{~b}$ \\
'Capdeboscq' & 12.8 & 1.1 & 12.7 & $39.1 \mathrm{ab}$ \\
'Flordaguard' & 12.5 & 1.1 & 12.4 & $40.2 \mathrm{ab}$ \\
'Nemaguard' & 12.7 & 1.1 & 12.1 & $40.0 \mathrm{ab}$ \\
'Okinawa' & 13.2 & 1.1 & 12.8 & $40.7 \mathrm{ab}$ \\
'Umezeiro' & 12.8 & 1.1 & 12.8 & $42.5 \mathrm{a}$ \\
\hline Average & $12.8 \mathrm{~A}$ & $1.12 \mathrm{~A}$ & $12.6 \mathrm{~B}$ & $35.4 \mathrm{~B}$ \\
\hline & \multicolumn{5}{c}{ 'Chimarrita' } \\
'Aldrighi' & $12.6 \mathrm{ab}$ & $0.4^{\mathrm{ns}}$ & $32.7 \mathrm{ab}$ & - \\
'Capdeboscq' & $12.5 \mathrm{~b}$ & 0.4 & $33.1 \mathrm{ab}$ & - \\
'Flordaguard' & $12.0 \mathrm{~b}$ & 0.4 & $30.3 \mathrm{~b}$ & - \\
'Nemaguard' & $12.5 \mathrm{~b}$ & 0.4 & $31.9 \mathrm{ab}$ & - \\
'Okinawa' & $12.3 \mathrm{~b}$ & 0.4 & $31.0 \mathrm{ab}$ & - \\
'Umezeiro' & $13.6 \mathrm{a}$ & 0.4 & $38.1 \mathrm{a}$ & - \\
\hline Average & $12.6 \mathrm{~B}$ & $0.43 \mathrm{~B}$ & $32.8 \mathrm{~A}$ & $44.6 \mathrm{~A}$ \\
\hline Effect & \multicolumn{5}{c}{ P-value (F test) } \\
Scion & 0.039 & $<0.001$ & $<0.001$ & $<0.001$ \\
Rootstock & 0.004 & 0.324 & 0.007 & 0.018 \\
Scion x Rootstock & 0.022 & 0.070 & 0.016 & 0.298 \\
\hline
\end{tabular}

(1) Uppercase letters compare scions according to the $\mathrm{F}$ test, at $5 \%$ probability, whereas lowercase letters compare rootstocks according to Tukey's test, at $5 \%$ probability. ${ }^{(2)}$ Average of scions. ${ }^{(3)}$ Significant interaction when $\mathrm{p}<0.25$. Means followed by equal letters do not differ significantly. ${ }^{\text {ns }}$ Nonsignificant. 
maturation point could be linked to a delay in the time of bud sprouting, as observed by Durner \& Goffreda (1992), or to a direct rootstock effect on the scion's metabolism, probably due to the transport of mRNA in the phloem, causing changes in gene expression (Harada, 2010). The value obtained in the present study for the SS/AT ratio is in alignment with those of Picolotto et al. (2009) for 'Chimarrita'.

The obtained results show that 'Umezeiro' cannot be considered a good rootstock in the conditions of replanting areas for the evaluated scions, due to high plant mortality. The method of propagation by seed, which causes genetic variability, associated with replanting conditions, could have intensified the incompatibility symptoms. However, fruits produced on 'Umezeiro' showed very good quality. Therefore, new studies must be conducted with this rootstock, with other scions, in replanting conditions. Regarding the other rootstocks, it can be highlighted that 'Capdeboscq' and 'Aldrighi' did not present plant death in any of the scions, which was associated with a good productive performance.

\section{Conclusions}

1. The 'Maciel' scion presents vegetative growth and yield superior to those of 'Chimarrita' on the rootstocks evaluated in replanting conditions.

2. The 'Chimarrita' scion grafted on 'Umezeiro' shows a delay in ripening and more attractive fruits than on the other assessed rootstocks.

3. The 'Umezeiro' rootstock reduces vegetative growth and yield of scions in replanting conditions.

4. The scions grafted on 'Capdeboscq' and 'Aldrighi' display a satisfactory agronomic performance in replanting conditions.

\section{Acknowledgments}

To Coordenação de Aperfeiçoamento de Pessoal de Nível Superior (Capes) and to Conselho Nacional de Desenvolvimento Científico e Tecnológico (CNPq, process 455.300/2014-3), for financial support.

\section{References}

ALONSO, J.M.; ESPADA, J.L. Influence of the rootstock on the agronomic performance of 'Jesca' peach under replant conditions. Acta Horticulturae, v.903, p.489-493, 2011. DOI: 10.17660/ ActaHortic.2011.903.67.
BENIZRI, E.; PIUTTI, S.; VERGER, S.; PAGÈS, L.; VERCAMBRE, G.; POESSEL, J.L.; MICHELOT, P. Replant diseases: bacterial community structure and diversity in peach rhizosphere as determined by metabolic and genetic fingerprinting. Soil Biology and Biochemistry, v.37, p.1738-1746, 2005. DOI: 10.1016/j.soilbio.2005.02.009.

BENT, E.; LOFFREDO, A.; YANG, J.; MCKENRY, M.V.; BECKER, J.O.; BORNEMAN, J. Investigations into peach seedling stunting caused by a replant soil. FEMS Microbiology Ecology, v.68, p.192-200, 2009. DOI: 10.1111/j.1574-6941.2009 .00668.x.

BERGAMASCHI, H.; MELO, R.W. de; GUADAGNIN, M.R.; CARDOSO, L.S.; SILVA, M.I.G. da; COMIRAN, F.; DALSIN, F.; TESSARI, M.L.; BRAUNER, P.C. Boletins agrometeorológicos da Estação Experimental Agronômica da UFRGS: série histórica 1970 - 2012. Porto Alegre: Universidade Federal do Rio Grande do Sul, 2013. Available at: <http://www.ufrgs.br/agronomia/joomla/ files/EEA/Srie_Meteorolgica_da_EEA-UFRGS.pdf $>$. Accessed on: Mar. 222015.

COMIOTTO, A.; FACHINELLO, J.C.; HOFFMANN, A.; GALARÇA, S.P.; MACHADO, N.P; PREZOTTO, M.E.; HASS, L.B. Desenvolvimento, produção e qualidade dos frutos de pessegueiros enxertados sobre diferentes porta-enxertos. Semina: Ciências Agrárias, v.34, p.3553-3562, 2013. Suplemento 1. DOI: 10.5433/1679-0359.2013v34n6Sup11p3553.

DURNER, E.F.; GOFFREDA, J.C. Rootstock-induced differences in flower bud phenology in peach. Journal of the American Society for Horticultural Science, v.117, p.690-697, 1992.

FREITAS, A.R. de; PRESOTTI, C.V.; TORAL, F.L.B. Alternativas de análises em dados de medidas repetidas de bovinos de corte. Revista Brasileira de Zootecnia, v.34, p.2233-2244, 2005. DOI: 10.1590/S1516-35982005000700010.

GALARÇA, S.P.; FACHINELLO, J.C.; BETEMPS, D.L.; HOFFMANN, A.; MARODIN, G.A.B.; PRETTO, A.; NUNES, F.S.; DIAS, F.P. Crescimento e desenvolvimento de pessegueiros 'Chimarrita' e 'Maciel' sobre diferentes porta-enxertos e locais de cultivo. Ciência Rural, v.43, p.219-224, 2013. DOI: 10.1590/ S0103-84782013000200005.

GUR, A.; COHEN, Y. The peach replant problem - some causal agents. Soil Biology \& Biochemistry, v.21, p.829-834, 1989. DOI: 10.1016/0038-0717(89)90177-6.

HARADA, T. Grafting and RNA transport via phloem tissue in horticultural plants. Scientia Horticulturae, v.125, p.545-550, 2010. DOI: 10.1016/j.scienta.2010.05.013.

JIMÉNEZ, S.; PINOCHET, J.; ROMERO, J.; GOGORCENA, Y.; MORENO, M.A.; ESPADA, J.L. Performance of peach and plum based rootstocks of different vigour on a late peach cultivar in replant and calcareous conditions. Scientia Horticulturae, v.129, p.58-63, 2011. DOI: 10.1016/j.scienta.2011.03.006.

LEINFELDER, M.M.; MERWIN, I.A. Rootstock selection, preplant soil treatments, and tree planting positions as factors in managing apple replant disease. HortScience, v.41, p.394-401, 2006.

LÓPEZ-ORTEGA, G.; GARCÍA-MONTIEL, F.; BAYO-CANHA, A.; FRUTOS-RUIZ, C.; FRUTOS-TOMÁS, D. Rootstock 
effects on the growth, yield and fruit quality of sweet cherry cv. 'Newstar' in the growing conditions of the Region of Murcia. Scientia Horticulturae, v.198, p.326-335, 2016. DOI: 10.1016/j. scienta.2015.11.041.

MCGUIRE, R.G. Reporting of objective colour measurements. HortScience, v.27, p.1254-1255, 1992.

NUNES, J.L. da S.; SOUZA, P.V.D. de; MARODIN, G.A.B.; FACHINELLO, J.C. Incremento no desenvolvimento do porta-enxerto de pessegueiro 'Okinawa', promovido por fungos micorrízicos arbusculares autóctones. Revista Ceres, v.58, p.223-231, 2011. DOI: 10.1590/S0034-737X2011000200014.

ORAZEM, P.; STAMPAR, F.; HUDINA, M. Comparison of ten peach rootstocks performance grafted with 'Redhaven'. European Journal of Horticultural Science, v.76, p.162-169, 2011.

PERECIN, D.; CARGNELUTTI FILHO, A. Efeitos por comparações e por experimento em interações de experimentos fatoriais. Ciência e Agrotecnologia, v.32, p.68-72, 2008. DOI: 10.1590/S1413-70542008000100010.
PICOLOTTO, L.; MANICA-BERTO, R.; PAZIN, D.; PASA, M. da S.; SCHMITZ, J.D.; PREZOTTO, M.E.; BETEMPS, D.; BIANCHI, V.J.; FACHINELLO, J.C. Características vegetativas, fenológicas e produtivas do pessegueiro cultivar Chimarrita enxertado em diferentes porta-enxertos. Pesquisa Agropecuária Brasileira, v.44, p.583-589, 2009. DOI: 10.1590/ S0100-204X2009000600006.

PINOCHET, P. 'Replantpac' (Rootpac ${ }^{\circledR}$ R), a plum-almond hybrid rootstock for replant situations. HortScience, v.45, p.299-301, 2010.

REMORINI, D.; FEI, C.; LORETI, F.; MASSAI, R. Observations on nine peach rootstocks grown in a replant soil. Acta Horticulturae, v.1084, p.131-138, 2015. DOI: 10.17660/ ActaHortic.2015.1084.16.

RUTTO, K.L.; MIZUTANI, F. Peach seedling growth in replant and non-replant soils after inoculation with arbuscular mycorrhizal fungi. Soil Biology and Biochemistry, v.38, p.2536-2542, 2006. DOI: 10.1016/j.soilbio.2006.03.012. 